International Review of Research in Open and Distributed Learning Volume 18, Number 4

June - 2017

\title{
Incentivizing the Production and Use of Open Educational Resources in Higher Education Institutions
}

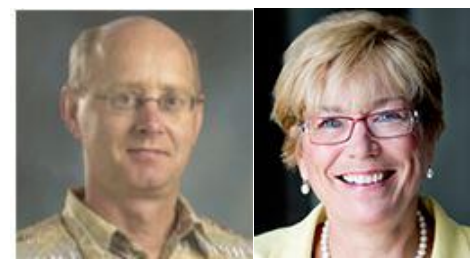

David Annand and Tilly Jensen

Athabasca University

\begin{abstract}
Substituting open educational resources (OER) for commercially-produced textbooks results in demonstrable cost savings for students in most higher education institutions. Yet OER are still not widely used, and progress toward large-scale adoption in most colleges and universities has been slow. This article reviews the literature informing financial and other issues that affect OER adoption. It describes the outcome of an ongoing, financially self-sustaining project at Athabasca University that has produced significant cost savings for the institution, maintained equivalent student learning outcomes and persistence rates, and enhanced aspects of the student learning experience. Based on the success of the project to date, broadly-applicable recommendations are suggested to reduce organizational impediments to the adoption of OER in higher education institutions.
\end{abstract}

Keywords: open education resources, behavioural economics, post-secondary education, higher education

\section{Introduction}

Kortemeyer (2013) asked a straightforward question: Why have open education resources (OER), now with over a 15-year history, failed to significantly disrupt the traditional teaching and business models of most higher education institutions? The growing number of OER initiatives sponsored by government and private philanthropy is well-documented (McGreal, Anderson, and Conrad, 2015; Gourley and Lane, 2009; Weller, 2014). OER use increases student satisfaction and generally produces equivalent or better student learning outcomes (de los Arcos, Farrow, Perryman, Pitt, and Weller, 2014; Fischer, Hilton, Robinson, and Wiley, 2015). 
Potential financial savings for students are large because the costs of OER are so much lower than commercially-produced textbooks. The College Board Advocacy and Policy Center (2016) noted the average U.S. undergraduate student attending public four-year on-campus education budgeted to spend almost $\mathrm{C} \$ 1,200$ per year on textbooks during the 2015-16 academic year. Senack and Donoghue (2016) stated that the cost of college textbooks has risen over the past decade at about four times the rate of general inflation. This now accounts for about $25 \%$ of the cost of an average student's higher education in the US. They surveyed almost 5,000 U.S. college and university students and reported that $30 \%$ of respondents now require student aid to pay for textbooks. Extrapolating across the U.S. undergraduate population, over $\mathrm{C} \$ 3$ billion of student aid is used for this purpose, in addition to the related interest burden placed on these often-marginalized students. The detrimental effect on a student's learning experience is commensurately large. About $65 \%$ of students do not purchase required commercial textbooks because of high cost, despite most recognizing that this will negatively affect their course results.

There are examples of increasing use of OER in higher education. Klein (2015) reported that as of September 2016, the University of Maryland University College will be using OER in all its undergraduate courses. Concern with costs to students was cited as the compelling reason. Ruth and Boyd (2016) reported that OpenStax OER texts are now used by about $20 \%$ of US degree-granting institutions, amounting to savings to students of over $\mathrm{C} \$ 39$ million in the 2015-16 academic year alone. The Open Education Textbook project sponsored by BCcampus has saved students an estimated Cdn $\$ 1.5$ million to date (Jhangiani, Pitt, Hendricks, Key, \& Lalonde, 2016). But despite these initiatives and the obvious benefits of OER textbooks, their use is still only a fraction of the total textbook market for higher education. Some of the realities limiting OER as replacements for commercial textbooks are discussed below.

\section{Factors Impeding OER Use}

Many obstacles to broader OER adoption have been cited in the literature. In a survey of over 2,00o U.S. faculty, Allen and Seaman (2014) found that the most significant barrier to OER adoption was the perception that too much faculty time was required to locate, evaluate, and incorporate material. A followup study of 3,000 U.S. faculty confirmed this (Allen \& Seaman, 2016). Concerns have been expressed about OER quality, and faculty issues like the potential loss of control over intellectual property, inertia, resistance to change, excessive workload, and absence of institutional support (Plotkin, 2010; Sclater, 2010; Bossu \& Tynan, 2011; Butcher \& Hoosen, 2012; Okonkwo, 2012; Armellini \& Nie, 2013; Feldstein, 2014; Weller, 2014; Jhandiani et al., 2016). Commercial publishers maintain sophisticated marketing channels and provide often-elegant instructional aids, adaptive learning, and assessment systems inextricably linked to educational content. These make it easier for faculty to opt for the status quo (Senack \& Donoghue, 2016).

Kortemeyer (2013) cited four main issues that prevented more widespread use of OER: time needed to discover and link suitable OER material into a suitable curriculum; lack of quality control and feedback procedures to improve content and reduce error; lack of faculty expertise in integrating OER into existing course management systems, and lack of faculty buy-in to the OER ideology. As well, faculty scholarship 
as it relates to OER development is difficult to evaluate, because impact factors and citation indices do not exist (unlike journals), and sales figures are not available (unlike textbooks authored for commercial sales). As a result, OER research is perceived as undervalued.

Many barriers to OER as replacements for entire textbooks arise in higher education institutions from the academy's historical reliance on commercial publishers and the industry's growing concentration. Senack and Donoghue (2016) noted that mergers and acquisitions have created a relative oligopoly in the U.S. higher education textbook market. Five publishers account for $80 \%$ of the market. Rival firms avoid competing against popular textbooks in certain subject areas. Publishers eschew meaningful measures of quality like relative student success, and focus instead on author reputation and extravagant textbook design. Weller (2014) concluded that there is a "long-standing cultural ecosystem" (p. 85) surrounding the current use of textbooks in higher education that has yet to be adequately disrupted by the OER movement.

Commercial publishers' time-worn revenue-generation strategies also continue. Senack and Donoghue (2014) noted that to maintain the market for new textbooks, publishers create trivial updates that require adoption of new, more expensive versions of a text, or customize texts to limit broad use and curtail the used textbook market. But the publishing industry has also developed tactics to generate new revenue streams. Over $80 \%$ of students incurred additional costs to gain access to publisher's online supplemental learning material and assessments. In response to the fact that OER drives the costs of educational content to zero, Wiley (2013) described how publishers have developed additional features like adaptive learning services that tailor instructional, feedback, and assessment activities to learner traits. These and other for-profit services have been closely tied to access to free digital educational content. With the introduction of e-texts, course content is no longer the personal property of students. Length of access time is restricted, as is the ability to re-sell texts by students. E-texts are priced so that the publishing industry's net revenues are increased despite the significantly lower production and distribution costs involved.

Non-financial changes to current digital publishing practices have been suggested. Wiley (2013) argued that in situations where proprietary services are bundled with OER content, the source code should be openly licenced, along with students' personal notes and annotations. Students should have the right to download information they create. Other solutions centre on changing the characteristics of the OER development process to resemble those of the open software movement. Most importantly, multiple and independent experiments incorporating feedback loops and the ' 5 Rs' of openness would result in better identification of content errors and design deficiencies, and produce a larger user community (Stacey, 2013; Weller, 2014, Wiley, 2015).

Others noted that administrators could encourage OER adaptation and use by marshalling staff expertise, allowing faculty time to create and adopt OER, funding research and development of OER by internal reallocation of revenue, tying support for open educational practices to the institution's mission and strategic plan, and encouraging more flexible instructional approaches (Jhangiani et al; Iioshoyi \& Kumar, 2008). Senack (2014) suggested that students should advocate more strongly for use of OER by their institutions. 
Wiley (2015) argued that raising awareness about OER is its most pressing need. OER fundamentally requires critical mass for success. This requires the participation of those further along the technology diffusion continuum described by Rogers (2003), especially early-majority and late-majority adopters. Wiley (2015) opined that adoption of OER may significantly accelerate once even $15 \%$ of faculty start using these resources because a self-reinforcing, virtuous cycle of greater use will beget greater awareness, which will in turn result in greater use. While this may occur, Rogers (2003) also noted that a valid competitive strategy for early- and late-majority technology adopters is to wait and merely use resources produced by others. This tendency may encourage greater OER use, but not until relatively complete OER substitutes for textbooks and related instructional and assessment aids are available. Wiley's suggested cascade of supporting developments thus seems all the more important: first, a large, successful track record of OER adoption, then recognition by institutions of the value of OER, followed by faculty incentives to develop and use OER.

Financial changes have been proposed, including a general call for publishers to alter their business models so that costs to students are reduced (Senack \& Donoghue, 2016). This will likely remain unheeded given that the generally-accepted, principal role of publicly-traded corporations is to maximize profit for shareholders. Various lists of OER funding models have been developed (Dholakia, King, \& Baraniuk, 2006; Downes, 2007), but most presuppose state or philanthropic funding. As Annand (2015) noted, this is transitory and requires institutions to continually compete for funds. Granting authorities still need to re-deploy scarce funds to encourage OER adoption in the face of competing resource claims by equally-worthwhile endeavours. There is a notable dearth of OER projects that survive beyond the duration of their start-up funding.

However, some successes have been noted. Senack (2015) reviewed the results of campus-based OER pilot project at five U.S. higher education institutions. On average, these projects saved students about C $\$ 128$ per course. At most of the participating campuses, small grants provided incentives for faculty to convert to OER. At one, a full-time staff member was hired to promote OER adoption and work directly with faculty. At University of Massachusetts, Amherst, $\mathrm{C} \$ 60,000$ of grants over four years produced total estimated savings of almost $\mathrm{C} \$ 1$ million in just the inaugural semester of each project. At Kansas State University, an investment of $\mathrm{C} \$ 96,250$ produced students savings estimated at more than $\mathrm{C} \$ 1.1$ million. At Tacoma Community College, an approximate $\mathrm{C} \$ 240,000$ outlay produced over more than $\mathrm{C} \$ 1.1$ million in student cost savings.

There are successful larger-scale OER initiatives in higher education as well, like MIT's Open Education Consortium, the OpenLearn project at the Open University of the United Kingdom, OpenStax College, and in Canada, the Open Textbook project sponsored by BCcampus. Klein (2015) reported that as of the September 2016, the University of Maryland University College will be using OER in all its courses. However, all these projects are well-supported by internal grants, or external grants from private donors or governments that have enabled them to develop a wide range of curricula. OER adoption is also seen as a source of competitive advantage. A project may be sustainable for a particular institution to the extent that it derives net, if indirect, benefits from attracting new students, facilitating more transparent accountability of taxpayer funds, fulfilling its public service role, or advancing the institution's reputation. (Gourley \& Lane, 2000; Weller, 2014). 
Some changes to the general financial model of OER production and use have been proposed. Cost efficiencies could be realized by centralizing OER aggregation and distribution, and forming membershipbased consortia (Stacey, 2010; Atkins, Brown, \& Hammond, 2007). De Langen (2013) suggested a nonmonetary exchange process where reciprocal services would be provided by institutional participants. The state would contribute some funds toward this, because students (and thus indirectly, taxpayers) would benefit from quality assurance processes this cash provided. Kortemeyer (2013) argued that an independent, user-pay equivalent of iTunes could be constructed to provide a common platform for combining and cataloguing OER, while perhaps providing a small financial reward to producers whose work is downloaded. Because resources would be accessible to a large number of users, only a small user fee per download would be required to sustainably fund the model.

These models or variants may eventually succeed, but at present there appear to be few if any functioning examples in the literature about how the adoption of OERs can result in stable, measurable, direct, internally-generated net revenue streams for higher education institutions, despite the large amounts of money spent on educational material each year and the potential cost savings for students. Developing a sustainable financial model for a process that in the end gives its product away is a critical issue for the OER movement (Wiley \& Gurrell, 2009; Barrett, Grover, Janowski, van Lavierena, Ojoa, \& Schmidta, 2009; Atkins, Brown, \& Hammond, 2007; Weller, 2014).

The case study described below illustrates an exception to this quandary. It describes the development of an OER textbook now used in an undergraduate introductory financial accounting course offered by Athabasca University's Faculty of Business.

\section{Description of the Project}

Athabasca University is located in Alberta, Canada. It has been accredited by the Middle States Commission on Higher Education since 2006. Since its formation in the 1970s as Alberta's fourth research-based, publicly-funded university, its mission has been to reduce barriers that traditionally restrict access to university-level education. To accomplish this, the institution has adopted open access policies in its undergraduate courses-for instance, offering courses almost exclusively by online education; admitting any adult regardless of prior education; arranging comprehensive transfer credit arrangements with other educational institutions; and pioneering work in prior, non-formal learning assessment for university credit. Many students work full-time and have other significant obligations, like supporting families. The average age of students is around 30 years. Most students study part-time. The University provides all instructional material including textbooks to students as part of their course fees.

Because of the self-paced nature of undergraduate courses, students need to be provided with additional resources and assistance. The University spends a considerable amount of time and financial resources preparing course materials or in many courses, "wrapping" additional resources around commerciallyproduced textbooks. A course production team generally consists of a contracted subject matter expert (SME), the course coordinator (a full-time faculty member, who may also act as SME), an editor/instructional designer, copyright officer, and instructional media technologist. 
The University's Faculty of Business offers an introductory financial accounting course as a requirement of its undergraduate business programs. The course consistently ranks as one of the top three courses at the institution in terms of annual enrolments. At present, about 1,500 students register for the course each year. Two editions of a commercial textbook were used in the course from 1989 to 2000. For several reasons, the publisher decided not to produce a third edition and in the mid-1990s the copyright reverted to the original author, Henry Dauderis. Shortly thereafter, Dauderis agreed that the textbook could be revised by (institution) and that this third edition could be used in its introductory financial accounting course. A small royalty was paid to the author.

Annual enrolments in the course were about 1,000 at that time. The University could purchase an equivalent commercial textbook for about $\mathrm{C} \$ 55$. Publishing the print-based text in-house reduced variable production costs to about $\mathrm{C} \$ 30$ per text, including royalties. Projected savings were estimated to be about $\mathrm{C} \$ 75$,000 over the estimated three-year life of the text before the next revision would be necessary. An estimated $\mathrm{C} \$ 55,000$ of one-time editing and production staff time was needed to convert, update, and edit this revised third edition. As a result of the estimated $\mathrm{C} \$ 20,000^{1}$ cost savings in the first three-year life cycle alone, the University committed funds and staff to the conversion process.

The third edition was published by Athabasca University Press in 1999. Copyright remained with the original author and there was no attempt to make the finished product available as an OER. However, a beneficial by-product of this process was that the university created and retained the digital files for the third edition of the text and ancillary materials (approximately 1,400 pages in all). The third edition was used in the introductory financial accounting course from 2000 to 2003 , until a new faculty member took over the course and replaced the text with one purchased from a commercial publisher for a package price of about $\mathrm{C} \$ 230$ per student (the package included web-based assessment). Meanwhile, the digital files of the third edition text were stored for over a decade.

In 2012, one of us (Annand) began to update and extensively revise these digital files. A fourth edition of the text was co-authored with (Dauderis) in 2014, who agreed to license this edition as an open educational resource under a CC-BY-SA-NC license².

Besides the pre-existence of digital files to work with, there were several factors that made this an attractive OER project:

1. There are few, if any, comprehensive introductory financial accounting texts available as OER.

2. Introductory financial accounting is a staple of postsecondary business programs worldwide so the potential market for adoption is large.

\footnotetext{
${ }^{1}(\$ 55-\mathrm{C} \$ 30) \times 1,000$ registrations per year $\times 3$ years $=\mathrm{C} \$ 75,000-55,000=\mathrm{C} \$ 20,000$

${ }^{2}$ Re-use, adaptation, and dissemination of derivatives requires attribution to the original authors. Derivative works must be similarly licenced. Production of only non-commercial works is permitted, unless by express consent.
} 
3. In 2010, Canada adopted International Financial Accounting Standards (IFRS). These prescribe reporting and disclosure requirements for most entities' financial statements in the great majority of nations. In addition, U.S. generally accepted accounting principles are gradually converging with IFRS. Thus the accounting principles described in the text are applicable to a large and growing number of countries.

On completion, the resources were submitted in .docx and .pdf formats to several OER repositories (ocw.athabascau.ca; MERLOT; BCcampus Open Textbook Project), though access to the complete solutions manual is restricted to vetted instructors.

In the meantime, this article's other author (Jensen) reviewed and managed the adaptation of the textbook for use in the University's introductory financial accounting course. The University, the copyright holder, and a third-party online learning software developer entered into agreements whereby the software developer converted the OER text to $\mathrm{html}$ format and linked this to a proprietary, relatively sophisticated, commercially-hosted database. Algorithmically-generated problems and extensive tailored feedback are coupled with individualized tracking of student progress and performance. Results are linked back into the University's learning management system. The latter has been noted as an important feature for faculty (Kortemeyer, 2013).

The conversion to OER textbook material occurred in 2013. Student completion and pass rates in the OER and previous non-OER versions of the course were compared. $6.41 \%$ fewer students withdrew from the OER version of the course. Of those students who completed the course, there was no difference in the number of students who passed in each version (86\%). Similar assessments were used in both versions of the course. These results parallel those of Hilton and Laman (2012), who likewise found that use of OER produced similar or better learning outcomes. However, as they also acknowledged, it is difficult to determine causality.

From an economic standpoint, the incremental cash outlay to the University as a result of incorporating the OER text into the introductory financial course is negligible. Pre-existing digital files from the third edition were available. The instructional materials were adapted by faculty as part of their normal workload. This is recognized as valid scholarly and research activity by the institution. In addition, because the material was to be used in an actual course, it was subjected to the normal quality assurance processes of the Faculty of Business.

As with the original project, cost savings to (institution) are significant because all instructional material continues to be provided to students as part of tuition fees. The cost of purchasing an equivalent commercially-available text and ancillary material is $\mathrm{C} \$ 229$ per registration in early 2017, and yearly enrolments in the introductory financial accounting course have remained at about 1,500 students. Under the terms of the agreement with the commercial software developer, the University is charged C $\$ 84$ per 
registration for the online, enhanced student evaluation and feedback. The cost savings to the University amount to about $\mathrm{C} \$ 217,500$ per year ${ }^{3}$.

Under this model, the value of the traditional "education content" of the text is zero, because the text and selected solutions will continue to be offered as freely-available OER within several openly-accessible repositories. It is as yet unknown whether other institutions and their faculty will consider the $\mathrm{C} \$ 84$ fee for the additional online review and feedback component a reasonable value proposition. They may opt for the basic model: a freely-available OER text in e-book format (or about $\mathrm{C} \$ 30$ as a print-on-demand textbook).

Several factors made this project feasible, including the availability of digital files that facilitated revision; the agreement of the copyright holder to release these materials under a Creative Commons licence; and institutional incentives to facilitate OER production and use. However, the most important factor for success is that course materials are provided to students as part of their tuition fees. Any savings accrue to the institution. The University therefore has a strong economic incentive to use OER, especially within high-enrolment courses.

Externally, there have been two broad types of educators interested in using the introductory financial accounting OER:

1. Accounting educators from developing countries who are primarily motivated by a philanthropic desire to reduce costs to students by replacing an expensive textbook with a free, adequate alternative from OER repositories.

2. Canadian higher institution administrators and faculty interested in combining the OER textbook with the commercial learning enhancement tools.

To date, the most common stumbling block to adoption by external parties is lack of chapter-by-chapter slide show summaries for use in-class by instructors. As a result, the third-party commercial provider is now funding development of these. ${ }^{4}$ They will be made available as part of either the bundled product from the third-party software provider, or the completely-free OER version residing in various repositories.

The ability to freely adapt the OER textbook material does not seem to have been a significant adoption factor. For both user types, the main attraction appears to be the availability of a relatively complete resource. This may be a function of the nature of introductory financial accounting itself, particularly its generally prescriptive nature, the well-established and entrenched practice of double-entry bookkeeping

${ }^{3}(\mathrm{C} \$ 229-84) \times 1,500$ yearly enrolments $=\mathrm{C} \$ 217,500$

4 The software developer can market the online text and enhanced assessment and feedback features to other post-secondary institutions. 
underlying the content, the similar curricula requirements of professional accounting organizations or governments, and the growing ubiquity of IFRS-based generally accepted accounting principles.

On the other hand, behavioural economics may be at play. Lacking incentives from their institutions like release time, recognition, and production assistance to create or adapt relatively comprehensive OER themselves, these academics want a fully-formed resource complete with adequate instructional aids to reduce needed effort and time on their part.

\section{Analysis}

The commercial publishing industry is an historical artifact. It originally provided the technology for the first mass distribution of the written word several hundred years ago when there were no alternatives. This radically reduced the cost of books, and was a boon to higher education and its students. The separation of knowledge creation by faculty from recording and distribution activities provided by publishers was economically useful and rational. Students benefitted from the arrangement by greater access to knowledge at a lower price. This value-added activity of commercial publishing continued for many years, despite the fact that the purchasing decision was made by an intermediary (the professor) while the purchase price was paid by the final consumer (the student).

Digitization and the Internet have radically changed the economics of knowledge production and distribution over the last two decades. But the ancient publishing model continues to exist in its essential form. Faculty select the textbooks used in their courses and thus make the financial decisions. The final consumers-students-pay. Allen and Seaman (2014) found that faculty select textbooks but students pay for these separately in $97 \%$ of surveyed institutions.

Publishers are thus primarily motivated by the needs of financial decision makers-faculty members-and not the purchasers. For faculty, commercial products provide free in-class presentation resources, exam banks, adaptive learning systems, and other features that make the teaching process easier. That is why these ancillary resources are such an important selling feature of any textbook. For-profit publishers provide these, and employ large numbers of sales representatives and other staff to assist faculty and otherwise reduce workload that can be devoted to other scholarly activities (Senack, 2014). Students pay for these features.

Pitt (2015) cited various examples where reducing student costs by adopting OER was seen as an important motivator of many educators, especially in U.S. community colleges with a large segment of economically disadvantaged learners. But in general, costs to students are only considered important when several other selection criteria have been satisfied. Allen and Seaman (2016) noted that the most compelling reason for faculty to consider OER adoption was the potential cost savings to students. $87 \%$ of faculty cited this factor as important or very important. However, when forced to rank cost as a selection factor, it was reported as very unimportant in their final decision. The fact that the cost of textbooks is not borne by those making the textbook selection decision is the most reasonable explanation for this. 
It is also described as one barrier among many to OER adoption (Weller, 2014; Senack, 2015; Senack \& Donoghue, 2016). In our view, however, this is the essential problem. New means of textbook production and distribution have evolved, and related costs have radically declined. However, textbook prices have not commensurately decreased because final consumer preferences have little effect on the market. Student interests are essentially ignored because they do not make the purchasing decision. The misalignment of the financial interests of faculty, their educational institutions, and students fundamentally accounts for the current characteristics of the post-secondary textbook market and resulting limitations on OER use. Lack of direct interaction between student consumers and commercial publishers, and market concentration in the hands of only a few firms inhibits price competition and thwarts operation of normal market forces (Senack, 2015; Senack \& Donoghue, 2016). It also can largely explain why OER is being adopted so slowly in the academy. Financial incentives are stacked in favour of commercial textbooks.

The key question is how this can be rectified. Fortunately, as is often the case in the field of behavioural economics, small changes can produce significant results. One option would be to remove the intermediaries (faculty members) from the purchasing process by letting students decide what textbook, if any, to use. This does not seem feasible and creates obvious problems for instructors and the educative process. Further, the degree-granting monopoly granted to higher education institutions means that their administrators and faculty will stay involved in the educative process for the foreseeable future, including textbook selection decisions.

What is needed, it is argued here, is a means to align the financial interests of the intermediaries (faculty and their institutions) and final consumers. Governments could decree that lower-cost OER be used by publicly-funded higher education institutions whenever possible, but this may be impractical in some fields and is open to interpretation. It also might be considered an infringement on academic freedom. As Annand (2015) argued, campaigning for additional government funding to encourage production and use of OER merely re-directs public money from one worthwhile endeavour to another, overall. As the case study described above illustrates, the most reasonable and feasible means to align the financial interests of intermediaries and final consumers in the post-secondary textbook market is for governments to decree that publicly-funded institutions should include the cost of all learning materials in their tuition fees.

On the face of it, this would seem like an irrelevant change and another administrative burden. Institutions would merely add the cost of commercially-produced textbooks to their fees. However, the important behavioural implication is that any subsequent cost reductions would be realized by the institution. Most higher education institutions have a strong incentive to reduce costs whenever possible in the face of budget constraints. Institutional administrators can choose to pass savings from OER use along to students by lowering fees, but based on past experience, they are much more likely to retain these to forestall further tuition hikes in the face of escalating costs in other areas. In the case study at hand, there have been virtually no complaints about cost savings remaining with the institution. Likely, this has not occurred because the quality of the instructional resources is perceived by students as equivalent or better. 
Realizing the potential savings that could accrue to the institution would prompt administrators to implement policies that encourage faculty to develop and adopt OER. By and large, educators are amenable to this in principle (Pitt, 2014). With appropriate internal incentives, most resistance to greater OER adoption should gradually decrease.

\section{Conclusion}

Several factors have been important for the successful development of the OER accounting text described herein. First, Athabasca University benefits financially from the development and use of OER. Operating costs are lowered when OER is adopted because the University's tuition fees include the costs of all instructional materials. Second, developing instructional material is recognized as valid scholarly activity for the University's faculty members. As a result, institutional needs (lower production costs) have been aligned with individual faculty incentives, and production and use of OER is encouraged.

A means to encourage more wide-scale behavioural change has also been proposed: governments should require that universities and colleges include the cost of textbooks in their tuition fees. This is necessary to align incentives for institutions, their faculty, and students to adopt OER.

The proposal does not prescribe a particular organizational form for the OER market. It merely provides the necessary foundation for the evolution of many possible OER production and distribution models. Once competing interests are aligned, any number of models for creating self-sustaining OER revenue streams can be developed. As Tuomi (2013) opined, many different types of OERs can help students learn. With appropriately-structured financial incentives, OER production and use could nimbly and economically adapt to the continuous changes in information and communication technology.

Kortemeyer (2013) observed that iTunes was successful because digitization and the advent of the Internet enabled a new, more efficient market for music creation and distribution. It provided consumers access to a wider range of music at a lower cost and thereby increased demand. But the crucial success factor was that the financial interests of music producers and consumers were aligned. Since the financial benefits were directly realized by consumers, successful music providers responded to the opportunity. Change occurred rapidly. Similarly, an OER equivalent of iTunes or any other model that may evolve is only feasible if the financial interests of students are aligned with those of their institutions and related faculty. The potential savings will encourage both the production and use of OER in as-yet to be realized forms, or make existing initiatives more successful and financially self-sustaining.

One possibility is that third-party for-profit service providers may be involved. The case study described above used the technical capabilities of a commercial online assessment provider to produce value-added activity in the form of sophisticated review and feedback. But importantly, the overall cost of instructional resources to the institution was significantly reduced. Also, and unlike the commercial publishing industry as a whole, the feature is not inextricably bundled with OER content. Other institutions and faculty are able to decide whether these discrete third-party functions are valuable enough to warrant the additional cost. There is no inherent bias against de-bundling the online version of the text from the thirdparty assessment material. Relatively complete, free, stand-alone OER resources are available from several repository sites. 
Once the financial interests of students, faculty, and educational institutions are aligned, any number of models could create self-sustaining OER revenue streams that will benefit higher education institutions and their students. With appropriately-structured financial incentives, OER production and use can flourish.

\section{References}

Allen, I. \& Seaman, J. (2014). Opening the curriculum: Open educational resources in U.S. higher education, 2014. Report published by Babson Survey Research Group. Retrieved from http://www.onlinelearningsurvey.com/reports/openingthecurriculum2014.pdf

Allen, I. \& Seaman, J. (2016). Opening the textbook: Educational resources in U.S. higher education, 2015-16. Report published by Babson Survey Research Group. Retrieved from http://www.onlinelearningsurvey.com/oer.html.

Annand, D. (2015). Developing a sustainable financial model in higher education for open educational resources. International Review of Open and Distributed Learning, 16(5). Retrieved from http://www.irrodl.org/index.php/irrodl/article/view/2133

Armellini, A., \& Nie, M. (2013). Open educational practices for curriculum enhancement. Open Learning, 28(1), 7-20. Retrieved from http://dx.doi.org/10.1080/02680513.2013.796286

Atkins, D., Brown, J., \& Hammond, A. (2007). A review of the open educational resources (OER) movement: Achievement, challenges, and new opportunities. Report to the William and Flora Hewlett Foundation. Retrieved from http://www.hewlett.org/uploads/files/ReviewoftheOERMovement.pdf.

Barrett, B., Grover, V., Janowski T., van Lavierena, H., Ojoa, A. \& Schmidta, P. (2009). Challenges in the adoption and use of OpenCourseWare: Experience of the United Nations University. Open Learning, 24(1), 31-38. Retrieved from http://www.tandfonline.com/doi/abs/10.1080/02680510802627803\#.U7bn1fldU8k

Bossu, C. \& Tynan, B. (2011). OER: new media on the learning landscape. On the Horizon, (19)4, 259-267. Retrieved from http://www.emeraldinsight.com/journals.htm?articleid=1953822

Butcher, N. \& Hoosen, S. (2012). Exploring the business case for open educational resources. Commonwealth of Learning. Retrieved from http://oasis.col.org/handle/11599/57

College Board Advocacy and Policy Center. (2016). Trends in college pricing 2015/16. New York: College Board. Retrieved from https://trends.collegeboard.org/college-pricing/figures-tables/averageestimated-undergraduate-budgets-2015-16 
de Langen, F. (2013). Strategies for sustainable business models for open educational resources. International Review of Research in Open and Distributed Learning, 14(2). Retrieved from http://www.irrodl.org/index.php/irrodl/article/view/1533/2485

de los Arcos, B., Farrow, R., Perryman, L.-A., Pitt, R. \& Weller, M. (2014). OER evidence report 20132014. OER Research Hub. Retrieved from http://oerresearchhub.org/about-2/reports/

Dholakia, U., King, W., \& Baraniuk, R. (2006). What makes an open education program sustainable? The case of connexions. Connexions cns.org. Retrieved from https://oerknowledgecloud.org/sites/oerknowledgecloud.org/files/36781781.pdf.

Downes, S. (2007) Models for sustainable open educational resources. Interdisciplinary Journal of Knowledge and Learning Objects, 3, 29-44. February 27, 2007. NRC 50353. Retrieved from file:///C:/Users/Public.08Do11/Downloads/5764249.pdf

Feldstein, M. (2014, Aug 18). OER and the future of knewton. $e$-Literate. Retrieved from http://mfeldstein.com/oer-future-knewton/

Fischer, L., Hilton, J., III, Robinson, T., \& Wiley, D. (2015). A multi-institutional study of the impact of open textbook adoption on the learning outcomes of post-secondary students. Journal of Computing in Higher Education, 27 (3), pp. 159-172. Retrieved from http://link.springer.com/article/10.1007/s12528-015-9101-x/fulltext.html.

Gourley, B. \& Lane, A. (2009). Re-invigorating openness at The Open University: The role of open educational resources. Open Learning 24(1), 57-65. Retrieved from http://www.tandfonline.com/doi/full/10.1080/02680510802627845\#.U7WgLfldU8k

Iioshyi, T. \& Kumar, M. (2008). Conclusion. In T. Iioshyi and M. Kumar (eds.) Opening Up Education. Cambridge, MA: MIT Press.

Jhangiani, R., Pitt, R., Hendricks, C., Key, J., \& Lalonde, C. (2016). Exploring faculty use of open educational resources at British Columbia postsecondary institutions. BCcampus Research Report. Retrieved from https://bccampus.ca/files/2016/o1/BCFacultyUseOfOER final.pdf.

Klein, G. (2015, August 27). Embedded digital resources are in, traditional text out at UMUC. WCET Frontier. Retrieved from https://wcetfrontiers.org/2016/02/18/oer-at-umuc/.

Kortemeyer, G. (2013) Ten years later: Why open educational resources have not noticeably affected higher education, and why we should care. Educause Review, Nov/Dec 2013. Retrieved from http://er.educause.edu/articles/2013/2/ten-years-later-why-open-educational-resources-havenot-noticeably-affected-higher-education-and-why-we-should-care. 
McGreal, R., Anderson, T., \& Conrad, D. (2015). Open educational resources in Canada 2015. The International Review of Research in Open and Distributed Learning, 16(5). Retrieved from http://www.irrodl.org/index.php/irrodl/article/view/2404.

Okonkwo, C. (2012). A needs assessment of ODL educators to determine their effective use of open educational resources. International Review of Research in Open and Distributed Learning, 13(4). Retrieved from http://www.irrodl.org/index.php/irrodl/article/view/1316

Pitt, R. (2015). Mainstreaming open textbooks: Educator perspectives on the impact of OpenStax College open textbooks. International Review of Research in Open and Distributed Learning, 16(4), pp. 133-155. Retrieved from http://www.irrodl.org/index.php/irrodl/article/view/2381

Plotkin, H. (2010). Free to learn: An open educational resources policy development guidebook for community college governance officials. San Francisco: Creative Commons. Retrieved from https://wiki.creativecommons.org/images/6/67/FreetoLearnGuide.pdf

Rogers, E. M. (2003). Diffusion of innovations (5th ed.). New York, NY: Free Press.

Ruth, D. \& Boyd, J. (2016, January 20). OpenStax already saved students \$39 million this academic year. Rice University News \& Media. Retrieved from http://news.rice.edu/2016/01/20/openstaxalready-saved-students-39-million-this-academic-year/.

Sclater, N. (2010). The organizational impact of open educational resources. In U.-D. Ehlers \& D. Schneckenberg, (Eds), Changing Cultures in Higher Education: Moving Ahead to Future Learning, pp. 485-497. Berlin: Springer-Verlag GmbH.

Senack, E. (2014). Fixing the broken textbook market: How students respond to high textbook costs and demand alternatives. Student PIRGs. Retrieved from http://www.uspirg.org/reports/usp/fixingbroken-textbook-market.

Senack, E. (2015). Open textbooks: The billion dollar solution. The Student PIRGs. Retrieved from: http://studentpirgs.org/sites/student/files/reports/The\%20Billion\%20Dollar\%20Solution.pdf

Senack, E. \& Donaghue, R. (2016). Covering the cost. Student PIRGs. Retrieved from http://studentpirgs.org/reports/sp/covering-cost.

Stacey, P. (2010). Foundation funded OER vs. tax payer funded OER - A tale of two mandates. Open Ed Conference 2010 Proceedings, Universitat Oberta de Catalunya. Retrieved from http://openaccess.uoc.edu/webapps/o2/handle/10609/5241

Stacey, P. (2013). Government support for open educational resources: Policy, funding, and strategies. International Review of Research in Open and Distributed Learning, 14(2). Retrieved from http://www.irrodl.org/index.php/irrodl/article/view/1537/2481 
Tuomi, I. (2013). Open educational resources and the transformation of education. European Journal Of Education, 48(1), 58-78. Retrieved from

http://onlinelibrary.wiley.com/doi/10.1111/ejed.12019/abstract

Weller, M. (2014). The battle for open: How openness won and why it doesn't feel like victory. Retrieved from http://dx.doi.org/10.5334/bam

Wiley, D. (2013, March 20). Buying our way into bondage: The risks of adaptive learning services. Iterating Toward Openness. Retrieved from http://opencontent.org/blog/archives/2754.

Wiley, D. (2015, December 3). Reflections on open education and the path forward. Iterating Toward Openness. Retrieved from http://opencontent.org/blog/archives/4082.

Wiley, D. \& Gurrell, S. (2009). A decade of development. Open Learning, 24(1), 11-21. Retrieved from http://www.tandfonline.com/doi/full/10.1080/02680510802627746\#.U7R6R ldU8k 